\title{
The Impact of the Coronavirus Pandemic on Small and Medium- sized Enterprises in Russian Federation
}

\author{
Christina Chernova ${ }^{1}$, Natalia Neklyudova ${ }^{1, *}$ \\ ${ }^{1}$ Institute of Economics, Ural Branch of the Russian Academy of Sciences, 29, Moskovskaya St., 620014, Ekaterinburg, Russia
}

\begin{abstract}
The purpose of the article is to analyse the impact of COVID-19 on small and medium-sized businesses in the Russian Federation. Data from the research company "Evotor", the unified register of small and medium-sized businesses, as well as data from the Central Bank of Russia were used as material for the study. Based on the results, it can be stated that the pandemic has affected the economy in different ways. A number of small and medium-sized businesses and their revenue decreased in 2021 compared to 2019. But at the same time, the sector of domestic tourism has grown over the period under review. The largest increase in the average revenue of hotels in 2021 compared to 2020 was observed in the Kaliningrad region, Krasnodar Krai and Moscow.
\end{abstract}

Keywords: SMEs; COVID-19; domestic tourism; Russian regions

\section{Introduction}

Most countries in the world use the tools of fiscal and monetary policy to support the economies in the wake of the coronavirus pandemic. In 2020, drop in household income and uncertainty about the future im the new conditions of lockdown caused a sharp drop in aggregate demand. In Russia, this led to the decline in interest rate to the historically lowest level of $4.25 \%$ (from 27 July 2020 to 21 March 2021).

The most serious consequences for the Russian economy were a drop in demand for Russian exports, the decrease in oil prices, and the fall of domestic currency (rouble). The crisis is expected to have more serious consequences for the Russian economy since the state is currently facing the pressure of sanctions. In addition, since the beginning of 2020 , the dynamics of GDP has been negative.

The reduction of interest rate to $4.25 \%$ was supposed to support aggregate demand and lending. The decrease in inflation expectations led to significant easing of monetary policy in the Russian Federation. However, the measure adopted could not bring significant results in the conditions of rouble depreciation by more than $20 \%$ against the US dollar and more expensive imports for businesses. In addition, the freezing of the economic activity, lockdown, has also negatively affected the effectiveness of this measure. In the short term, lower interest rates are unable to stimulate growth if most economic activities are banned.

Measures to reduce regulation, which were aimed at maintaining liquidity in the economy, were more pronounced. This can be explained by the fact that most economic activities were frozen, with many financial institutions facing problems [1].

Small and medium-sized enterprises in Russia seriously suffered from the pandemic. The negative effects have affected $69 \%$ of enterprises in the SME sector. At the peak-lockdown, 56.1\% of enterprises were closed. According to surveys conducted by the SME Ombudsman, in 2020, a drop in demand affected $80 \%$ of enterprises, and to date, demand has not recovered for $52.6 \%$ of enterprises [2]. The turnover of small enterprises (microenterprises not included) decreased by 3.1 trillion roubles in 2020 [3]. The share of small enterprises with loan debts (including overdue ones) in the total number of small enterprises increased from 20 to $30 \%$ in 2020 [4].

The most severe blow of the pandemic occurred in April and May 2020, the stabilization of economic processes was outlined in June. Some researchers note that microenterprises and small enterprises had more opportunities for dismissing their employees; therefore, Russian regions with a high share of small enterprises in the economy are more susceptible to increased unemployment than the regions where the economy is based on large enterprises. The most vulnerable sectors were trade and services, transport, construction, and industry [5].

Based on the data from January to June 2020, Obraztsova et al. concluded that the average monthly decrease in the number of small business entities accounted for more than $2.5 \%$, with the number of employees decreasing by an average

\footnotetext{
* Corresponding author: nnp81@mail.ru
} 
of $3.2 \%$ per month. The authors of the article concluded that in general, medium-sized enterprises suffered less than small enterprises. In the first half of 2020, the reduction in the number of "young" firms set up in the preceding 3 months exceeded $19 \%$ due to the pandemic and quarantine measures. According to the calculations of the authors, this figure exceeded 30\% in the Tula region, Krasnoyarsk Territory, St. Petersburg, and Moscow [6].

Epidemics in general can be an incentive to introduce new business models and technologies. For example, in 2003, an outbreak of pneumonia led to the introduction of online shopping by Chinese consumers, which accelerated the growth of a Chinese holding company operating in the field of online commerce, Alibaba [7]. The coronavirus pandemic has greatly affected the migration processes in society. Migrants quickly lost stable wages and their jobs due to the lockdown. The closure of borders reduced their mobility and migrants could not return home to their families.

The countries donor of labour force experienced a sharp drop in the stable flow of funds from Russia, which accounted for a significant percentage of their total GDP. In addition, hundreds of thousands of unemployed (possibly infected) migrants were forced to return to their homeland. In turn, Russia lost a source of cheap labour. In addition, the cost of moving between states has increased due to the lack of transport, the need to pay for covid tests, the use of various modes of transport for transfers [8].

The coronavirus pandemic and self-isolation of Russian citizens led to a collapse in demand for passenger taxi services by $20-50 \%$ or more in the spring of 2020 . The economic problems that arose due to this collapse complicated even more the solution of the problems that had existed before the crisis in the taxi market of the Russian Federation [9].

Decrease in profit negatively affects the activities of any business. Due to the difficulty in complying with the rules of social distancing, in some cases, enterprises were forced to curtail their activities for a long period. The most affected sectors of the economy include the leisure sector, trade in non-food products, and hospitality sector. Forced suspension of activity affected mostly the construction sector and social services, some sectors of the manufacturing industry, fishing, forestry, and agriculture. The decline in commuting dramatically reduced the demand for public transport. However, at the same time, online sales increased, which led to a change in consumer preferences and increase in demand for delivery services. Consequently, the damage to those companies that were able to reorient themselves in the new conditions turned out to be less. In addition, over time, enterprises were able to evaluate the effectiveness of work from home, as it has allowed them to reduce the cost of maintaining offices [10].

Now the restaurant owners have to search for new formats that would take into account customer requests. On the one hand, guests are becoming more demanding; on the other hand, rather thrifty economical due to the consequences of the coronavirus pandemic [11].

The coronavirus pandemic has undoubtedly affected all banks, reducing their activities. However, since the second half of 2020, there has been an increase in assets among 59\% of participants in the banking market [12]. The quality of banks' loan portfolios is of fundamental importance for interbank competition. In the medium term, the Bank of Russia assumes that there will be an increase in overdue loan debt and poor loan servicing in the banking sector. But there is a possibility of granting credit holidays or restructuring loans to borrowers affected by the effects of the coronavirus. Large banks, such as VTB and Sberbank provided significant support to branches of small and medium-sized enterprises affected during the introduction of self-isolation in 2020 in the form of interest-free irrevocable loans.

It should also be noted that in the middle of 2020, there was a decrease in the number of deposits, as depositors decided to purchase daily goods and, fearing a strong price increase in the future, made purchases for the future [13].

The latest support measures due to the coronavirus pandemic of small and medium-sized enterprises at the federal level include the following: According to the Resolution of the Government of the Russian Federation of September 8, 2021, № 1520 scheduled inspections of small enterprises will not be carried out in 2022 [14]. Medium-sized and small enterprises have the opportunity to receive a subsidy, provided that regional anti-covid measures apply to them [15]. The Ministry of Economic Development will provide a monthly subsidy to banks in order to compensate for the commission paid by enterprises for transfers under the fast payment system from July 1 to December 31, 2021. Banks will transfer subsidies to customer accounts [16].

\section{Methodology}

We analysed statistical data before and during the coronavirus pandemic in the Russian Federation. The data were obtained from the Evotor research company, the unified register of small and medium-sized enterprises, and from the Central Bank of Russia for the years 2019, 2020, and 2021. Evotor is an IT company, an ecosystem of technologies for automation of small, medium-sized and large enterprises. Since 2016, it has been a leader of technological transformation in small and microenterprises. This company is the largest Russian manufacturer of smart online cash registers: over 800,000 Evotor smart terminals have been activated in the country in the last 5 years. Every fourth entrepreneur in Russia uses Evotor. They provide more than 850 services for business management in the app store "Evotor.Market". 


\section{Results and Discussion}

According to IT company Evotor in June 2021, hotels located in the Russian Federation increased their average revenue by $82 \%$ compared to 2020 . Evotor used the information from the receipts of 750,000 Evotor terminals in the Hotel segment for June 2019, 2020, and 2021 to determine the average revenue per terminal [17].

Table 1 shows that the largest increase in the average revenue of hotels in 2021 compared to 2020 was observed in the Kaliningrad region, Krasnodar region, and Moscow.

Table 1. Dynamics of average revenue of hotels in 2021 compared to 2020 and 2019, percentage

\begin{tabular}{|l|c|c|}
\hline \multicolumn{1}{|c|}{ Russian regions } & $\begin{array}{c}\text { Growth compared to June } \\
\mathbf{2 0 2 0}\end{array}$ & $\begin{array}{c}\text { Growth compared to June } \\
\mathbf{2 0 1 9}\end{array}$ \\
\hline Sverdlovsk region & 76 & 4 \\
\hline Republic of Tatarstan & 71 & 31 \\
\hline Republic of Karelia & 68 & 18 \\
\hline Irkutsk region & 37 & 19 \\
\hline St. Petersburg & 130 & 13 \\
\hline Moscow & 200 & 22 \\
\hline Kaliningrad region & 220 & 63 \\
\hline Krasnodar region & 200 & 36 \\
\hline
\end{tabular}

Source: Author based on the data of Evotor [17]

The increase in the average revenue of Russian hotels can be explained by the fact that in June 2021, the demand of Russians for holidays within the country increased due to the limited opportunities for recreation abroad. For example, tourists from Russia have been deprived of the opportunity to go on vacation to Turkey since 15 April 2021. Flights to this country were not resumed until 22 June 222021.

The analysis of the unified register of small and medium-sized enterprises shows that in all federal districts of Russia, the number of small and medium-sized enterprises has decreased in 2021 compared to 2019, except for the Central Federal District, where the value increased by $0.44 \%$ compared to 2019. In 2021, the increase in the number of small and mediumsized compared to 2020 was $3.9 \%$ in the Central Federal District, $0.52 \%$ in the North-Western Federal District, $1.92 \%$ in the North Caucasus Federal District, $0.44 \%$ in the Volga Federal District, 0.08\% in the Far Eastern Federal District. However, this indicator decreased by $0.26 \%$ in the Southern Federal District, by $0.17 \%$ in the Ural Federal District, and by $0.2 \%$ in the Siberian Federal District by $0.2 \%$ (Figure 1 ).

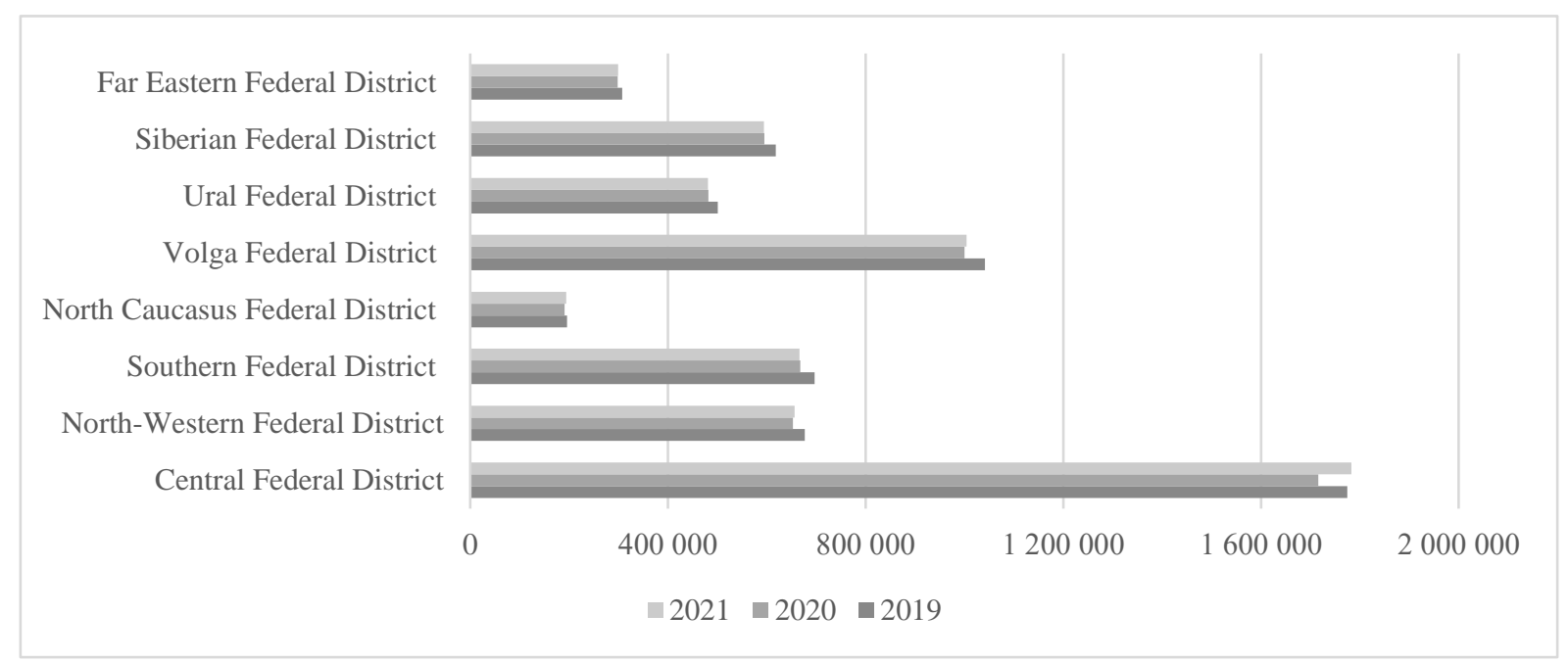

Figure 1. Number of small and medium-sized enterprises in Russia by federal districts

Source: Author based on the data from unified national register small and medium-sized business entities [18]

In addition, we concluded that the number of medium-sized enterprises in the Russian Federation grew during the pandemic (by $3.4 \%$ in 2020 compared to 2019 and by 5.5\% in 2021 compared to 2019). This does not apply to microenterprises and small enterprises, as the number of microenterprises decreased by $3.7 \%$ in 2020 compared to 2019 , and this indicator in Russia increased by $1.5 \%$ in 2021 compared to 2020 . The number of microenterprises decreased by $3.4 \%$ in 2020 compared to 2019 , and this indicator decreased by $1.8 \%$ in 2021 compared to 2020 (Table 2). 
Table 2. Number of firms in Russia before and during the pandemic by forms of entrepreneurship

\begin{tabular}{|c|c|c|c|}
\hline & $\mathbf{2 0 1 9}$ & $\mathbf{2 0 2 0}$ & $\mathbf{2 0 2 1}$ \\
\hline microenterprises & $5,570,745$ & $5,367,233$ & $5,445,653$ \\
\hline small enterprises & 225,556 & 217,951 & 213,990 \\
\hline medium-sized enterprises & 16,666 & 17,239 & 17,576 \\
\hline
\end{tabular}

Source: Author based on the data from unified national register of small and medium-sized enterprises [18]

The number of banks in Russia decreased by $23 \%$ as of 1 September 2021 compared to 1 January 2019. This indicator decreased monthly during the monitored period (Figure 2).

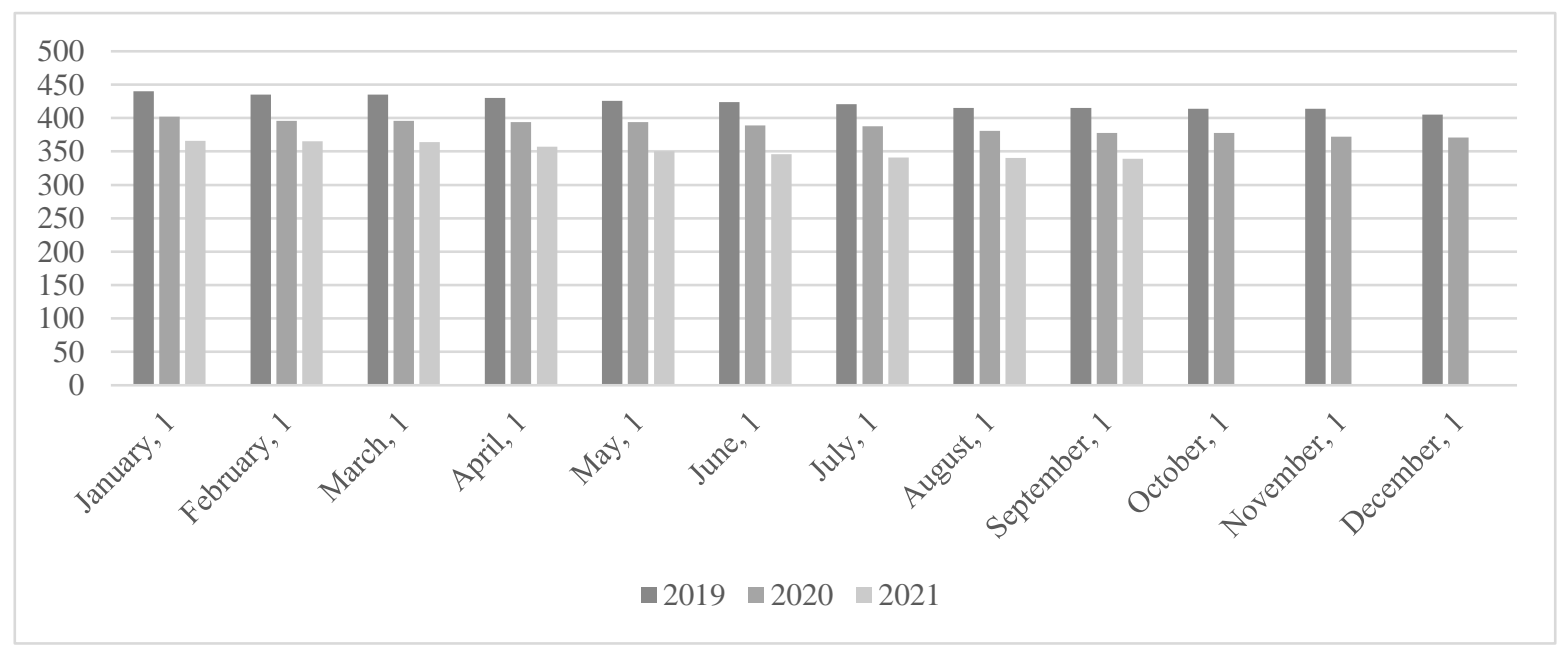

Figure 2. Quantitative characteristics of Banking Sector of the Russian Federation in 2019-2021

Source: Author based on data from the Central Bank of the Russian Federation [19]

\section{Conclusion}

The Covid-19 pandemic has affected sectors of the economy in a different way. Some industries have been seriously affected, while others suffered less. The tourism industry is considered to be one of the most affected sectors of the economy due to the introduction of restrictive measures to stop the spread of the coronavirus disease. Domestic tourism has become a trend this year in Russia. People who are tired of a prolonged regime of self-isolation prefer to make short trips at weekends. In the current situation, the Russians prefer travelling by car to flying. Tourist places have become more popular, trips to which were planned, but long postponed. Instead of hotels, travellers prefer cheaper alternatives, e.g. apartments where they can cook without having to visit cafes or restaurants. Accommodation is booked mainly using aggregators or hotel websites. Thus, while most small and medium-sized enterprises have been seriously affected by COVID-19, the pandemic works in favour of domestic tourism. Russian government, for its part, has also provided substantial support to domestic tourism, in particular in the form of returning part of the funds spent on trips to Russia, the so-called tourist cashback. Thus, tour operators and accommodation facilities - hotels, hotels, hostels - were provided some support. Currently, we are expecting the winter season. As usual, ski resorts are very popular at this time. If ski resorts are open, it would be advisable to resume the tourist cashback programme so that the Russians start to prefer domestic destinations for their holidays again.

The article is prepared under the plan of the Institute of Economics of the Ural Branch of RAS for 2021-2023.

\section{References}

1. Y. K. Zaytsev. Monetary and fiscal policy measures during the COVID-19 economic crisis in Russia. Finance: Theory and Practice. 24(6), 6-18 (2020)

2. Institute for the Economics of Growth P. A. Stolypin. Special report of SME Ombudsman to the President of the Russian Federation - 2021 [online]. Available at: http://doklad.ombudsmanbiz.ru/2021/7.pdf (2021)

3. Rosstat. Institutional transformations in the economy [online]. Available at: https://rosstat.gov.ru/folder/14036?print=1 (2021) 
4. Central Bank of the Russian Federation. Loans to small-and medium-sized enterprises grow by $22.6 \%$ in 2020 [online]. Available at: https://cbr.ru/press/event/?id=9619 (2021)

5. L. Yemelyanova, A. V. Lyalina. The labour market of Russia's Kaliningrad exclave amid COVID-19. Baltic Region. 12(4), 61-82 (2020)

6. O. I. Obraztsova, A. Y. Chepurenko. SME Policy in the Russian Federation: Renewal After the Pandemic? Public Administration Issues. 3, 71-95 (2020)

7. P. A. Esin. World market development scenario in the context of the coronavirus crisis. Izvestiya VUZ. Applied Nonlinear Dynamics. 28 (2), 158-167 (2020)

8. S.V. Ryazantsev, I. N. Molodikova, A.D. Bragin. The effect of COVID-19 on labour migration in the CIS. Baltic Region. 12(4), 10-38 (2020)

9. Y. Ezrokh. State Regulation of the Russian Passenger Taxi Market: Accumulated Problems and Solutions. Economic Policy. 15(4), 138-163 (2020) doi:org/10.18288/1994-5124-2020-4-138-163

10. I. Miles, V. Belousova, N. Chichkanov, Z. Krayushkina. The Impact of the Coronacrisis on KlBS Sector. Foresight and STI Governance. 15(1), 6-18 (2021) doi:org/10.17323/2500-2597.2021.1.6.18

11. I. N. Fedeneva, I. Y. Sewruikov, O. V. Leushina, R.A. Yakshigulov. Public Catering in the Structure of Tourist Services (on the Example of Novosibirsk). Human. Sport. Medicine. 21(1), 166-170 (2021)

12. RBC. Russian banks have shown a record growth in assets for six years [online]. Available at: https://www.rbc.ru/finances/25/12/2020/5fe482489a79476ad2ed7afd (2020)

13. O. Y. Donetskova. Interbank competition in the Russian banking market. Finance: Theory and Practice. 25(1),143156 (2021) doi:org/10.26794/2587-5671-2021-25-1-143-156

14. GARANT-SERVICE. The Resolution of the Government of the Russian Federation of September 8, 2021 № 1520 "On the specifics of conducting scheduled control (supervisory) activities in 2022, scheduled inspections in relation to small businesses and on amending certain acts of the Government of the Russian Federation» [online]. Available at: https://www.garant.ru/products/ipo/prime/doc/402677354/ (2021)

15. GARANT-SERVICE. The Resolution of the Government of the Russian Federation of September 7, 2021 № 1513 "On approval of the Rules for Granting Subsidies from the federal budget in 2021 to small and medium-sized businesses and socially oriented non-profit organizations operating in municipalities most affected by the deterioration of the situation as a result of the spread of a new coronavirus infection»[online]. Available at: http://www.garant.ru/products/ipo/prime/doc/402697350/ (2021)

16. Ministry of Economic Development of the Russian Federation. Reshetnikov: 53 banks compensate businesses for 100\% commission for quick payments. Available at: https://www.economy.gov.ru/material/news/reshetnikov_53_banka_kompensiruyut_biznesu_100_komissii_za_by strye_platezhi.html (2021)

17. EVOTOR. The turnover of Russian hotels in June exceeded the pre-pandemic level. [online]. Available at: https://evotor.ru/research/oborot-rossijskih-gostinits-v-iyune-prevysil-dopandemijnyj-uroven/ (2021)

18. Federal tax service of Russia. Unified national register small and medium-sized business entities [online]. Available at: https://rmsp.nalog.ru/index.html (2021)

19. Central Bank of the Russian Federation. Quantitative characteristics of Banking Sector of the Russian Federation [online]. Available at: https://cbr.ru/statistics/bank_sector/lic/ (2021) 